\author{
Egdūnas Račius" \\ Institute of International Relations and Political Science of the University of Vilnius \\ Lithuanian Military Academy
}

\title{
The Globality of Terrorism: a View from Lithuania
}

\begin{abstract}
Although Lithuania by now has been a member of the international antiterrorist coalition with all the issuing consequences (including its international commitments and new threats for its safety) for more than three years, studies of and research on terrorism in it remain in the embryonic phase. There are practically no contributors writing about the terrorism phenomenon in the Lithuanian language. As a result, there is no discourse about this sphere of studies. This means that so far no well defined terminology and standing conventions of academic parlance have been introduced, which would enable to go deeper into not only the nature of terrorism as a phenomenon (this is being done for at least forty years in the world) but also the perception of terrorism here, in Lithuania.

Reasons which stimulate terrorism, the motivation and goals of terrorists, the perception of the reality of threats as well as readiness to deal with them on both political and social levels - these are the subjects of this article. Though the objective of this article is not to carry out a comparable analysis with the situation and practice of other states, the particular case of Lithuania is conceptualized in the perspective of the international terrorism and global antiterrorist drive.

A peculiar pattern for this article was a recent (published in the spring of 2004) study "International Terrorism and Finland" by Toby Archer, where the threats of terrorism to Finland are analyzed.
\end{abstract}

\section{Introduction: the International Terrorism and the Struggle against it in the Perspective of the Global Binary Opposition}

Until today, there is no universally accepted definition of terrorism in the world (this, first of all, applies to the United Nations System), though there are more than a hundred definitions proposed by separate states, international organizations and independent institutes. It happened to be so that the definition of terrorismas

\footnotetext{
* Dr. Egdūnas Račius is associate professor and head of the Centre for Asian and African Studies of the Institute of International Relations and Political Science of the University of Vilnius; associate professor of the Political Science Department, Lithuanian Military Academy. Address: Vokiečiu g. 10, LT-01130 Vilnius, Lithuania, tel. +370-5-2514130, e-mail - egdunas.racius@cr.vu.lt
} 
well as terrorism itself became an instrument of political manipulations. ${ }^{1}$ Consequently, no official definition of terrorism will be followed in this article. However, talking about threats of terrorism and readiness to deal with them without any working definition might be deliberately or unwillingly interpreted incorrectly. Seeking to avoid such possible sequence of events, the author's formulated definition of the terrorism is given below.

Thus, terrorism is a politically motivated, premeditated and continual illegal practice of violence or threatening to employ such violence against civilians, who do not belong to any state military or paramilitary structures, or against nonmilitary installations, and which is committed by antisystemic non-state actors, who, through bullying society as a whole or its separate segments, seek to change the existing sociopolitical situation.

It has become classical to distinguish between terrorist groups that vend religious motivation and ideals and those, which do not give prominence to any religious aspects. The latter are divided into two types - ethnic/ nationalist and ideological. These are not necessarily antireligious (though Marxist groups that acted actively in the 1970's and 80's of previous century were underlyingly hostile in respect to religion), but they do not use religious terminology in their rhetoric, there are practically no religious symbols in their symbolism. Quite contrary, the whole activities of the groups that are ascribable to religious terrorism are permeated by religious spirit armed combat is justified through religious texts, the goals are coated with religious imperatives. It has to be admitted that terrorist groups of a nationalist nature sometimes use religious symbolism that is correspondent to their ethnic group, this way virtually erasing the line between nationalist and religious terrorism.

While the religious (Muslim) terrorism is ever intensifying, the response of the international community to its threats intensifies likewise. Although the antiterrorist measures around the globe have been employed already for more than three decades, the antiterrorist drive, which started in the autumn of 2001, has no analogical predecessor. The world entered a new era of international terrorism and global struggle against it.

In the today's constellation of international relations, it is possible to talk about emergence of a particular binary opposition which, of course, only as a far cry resembles the one that had existed during the Cold War. ${ }^{2}$ The denominator of the newly born contemporary opposition is the complex fusion of the threats stemming

${ }^{1}$ The best example of this is the decades old disagreement regarding the concept of "state terrorism" and the distinction between "terrorists" and "freedom fighters". For example, the Organization of the Islamic Conference in the Annex to its Resolution Nr. 59/26-P of 1999 confirms "the legitimacy of the right of peoples to struggle against foreign occupation and colonialist and racist regimes by all means, including armed struggle to liberate their territories and attain their rights to self-determination and independence in compliance with the purposes and principles of the Charter and resolutions of the United Nations. In the Article 2 of the same Annex, it is stated that 'Peoples' struggle including armed struggle against foreign occupation, aggression, colonialism, and hegemony, aimed at liberation and self-determination in accordance with the principles of international law shall not be considered a terrorist crime." http://www.oic-un.org/26icfm/c.html, November 11, 2004.

${ }^{2}$ This is sometimes mentioned by the experts analyzing the international anti-terrorist drive. See, for example, Aliboni R. Current Issues on Terrorism: Global vs. National Terrorism, State- vs. Terrorism-Violence, Instituto Affari Internationali, 2002. 
from the international terrorism and weapons of mass effect. In this way, on one side, there are the countries which are subsumed to be 'exporters' of terrorism (firstly, Arab and also some other Muslim states, which in the American but occasionally also in the European political discourse are referred to as 'rough' and/ or 'failed' states) while on the other side, there are those countries which (of course, not of their own will) have become 'importers' of terrorism and whose societies and governments are determined to use all resources and means available to them to prevent the import of this undesirable product. 'Export' and 'import' here however should not be understood in a strictly geographical sense because the so-called 'terrorism exporting countries' also suffer from terrorism on their own soil - Turkey, Morocco, Algeria, Saudi Arabia, Pakistan, Palestine, Iraq - in all these countries terrorist attacks swooped away tens and sometimes even hundreds of lives.

In the autumn of 2001, the President of the USA, simplifying and vulgarizing this binary opposition, defined it in this way: a particular state is either on the side of the fighters against the import of terrorism or on the side of the terrorism exporters. ${ }^{3}$ The head of the U.S. administration did not foresee any third option. By the way, the same binary opposition has been confirmed by Antanas Valionis, the Minister of Foreign Affairs of Lithuania (during the International conference 'International terrorism - a challenge to contemporary world', which took place on April 18, 2004, in Vilnius). In his speech the Minister speculated that "in the fight against terrorism there can be no half allies, no half enemies and no half measures." ${ }^{4}$ However, the reduced system of ideal types in reality often becomes a much more complex formation, where political and social actors have features, which are characteristic to at least several types, and, at the same time, filled to capacity with features that are found in none of those types. Therefore, it would be appropriate to talk about 'in-between' positions between the ideal types. In this particular case, we can talk about countries, which are neither exporters of terrorism, nor its importers. Doubtlessly, potentially every country can become an importer. One can also talk about 'transit' countries, through the territories of which terrorism is exported or can potentially be exported, even though their governments can identify themselves as fighting against terrorism.

Today, terrorism has become global as well as international. 'Global', because the geography of terrorist attacks during the last decade or so (approximately from the end of the Cold War) spread in the way that there are more states, which have suffered from terrorism than those which have not yet. 'International', because terrorist acts are organized by groups of people, whose homelands might be thousands of miles away from the place of the terrorist attack and also from each other. As it is

${ }^{3}$ President George W. Bush, in his speech on October 7, 2001, said the following: "Every nation has a choice to make. In this conflict, there is no neutral ground. If any government sponsors the outlaws and killers of innocents, they have become outlaws and murderers, themselves. And they will take that lonely path at their own peril." http://www.whitehouse.gov/news/releases/2001/10/ 20011007-8.html, November 11, 2004.

${ }^{4}$ Valionis, A. "International Response to Terrorist Threat: no Half Allies", Lithuanian Foreign Policy Review, 2002, vol. 1 (9), p. 18.

5 For the discussion on distinction between international/global and nationalistic/ regional terrorism, see Aliboni R. Current Issues on Terrorism: Global vs. National Terrorism, State- vs. Terrorism-Violence, Instituto Affari Internationali, 2002. 
argued in the Report of the Policy Working Group on the United Nations and Terrorism, "terrorism in a single country can readily become a threat to regional peace and security owing to spill-over effects, such as cross-border violence and the creation of refugee populations. It is therefore difficult to draw sharp distinctions between domestic and international terrorism." 6

However, the process of 'globalization' and 'internationalization' of terrorism started at least a few decades earlier. The 1960's could be considered to be the beginning of the 'globalization' of terrorism, when, inter alia, civilian airliners with passengers onboard started being hijacked. ${ }^{7}$ It was then that the international community for the first time took a serious look at the threats of terrorism - during one and a half decades (between 1963 and 1980) the UN alone passed six international conventions aimed at curbing terrorism. During this same period, two regional conventions were also adopted - the Organization of the American States in 1971 passed the 'Convention to Prevent and Punish Acts of Terrorism Taking the Form of Crimes against Persons and Related Extortion that are of International Significance' and the European 'Convention on the Suppression of Terrorism' was adopted in 1977. ${ }^{8}$ Unfortunately, neither conventions nor the measures, which had since been employed, could reduce the threat of terrorism. On the contrary, terrorism gradually intensified, when it peeked with an unprecedented number of victims in the Fall of 2001.

\section{Lithuania and terrorism: preparedness to deal with the threats of the international terrorism}

The then Minister of Defense of Lithuania Linas Linkevicius compared the threats of contemporary terrorism to Europe with the threats of Fascism before the World War II. He also warned that some European states still do not fully realize the extent of the threats of terrorism. ${ }^{9}$ Therefore, seeking to evaluate the perception of the threats of terrorism in Lithuania, it is necessary to identify those threats. In Lithuania, threats stemming from terrorism are identified in at least several documents authored by the Seimas, the Government and other commissioned public institutions.

The most important publicly available document of this type seems to be the "National Security Strategy of the Republic of Lithuania" (NSS), passed in May of 2002. In the article 1.5, it states that "the agenda for the security policy of the Repub-

\footnotetext{
${ }^{6}$ Report of the Policy Working Group on the United Nations and Terrorism, 2002, http://www.un.dk/ doc/A.57.0273_S.2002.875.pdf, http://www.globalsecurity.org/security/library/report/2002/unwrkng-grp-terrorism.htm, November 11, 2004.

${ }^{7}$ B. Raman in his "Plane hijacking: in perspective" provides data of the dramatic increase in plane hijacking in the end of the 1960's: if between 1948 and 1957 only 15 plane hijackings were reported in the whole world, and some 48 between 1958 and 1967, in the year 1968 alone there were 38 plane hijacking, and in 1969 even 82 - the highest hijacking rate per year. In the ten years between 1968 and 1977, 414 planes were hijacked. South Asia Analysis Group, http://www.saag.org/papers2/ paper103.html, November 11, 2004.

${ }^{8}$ The latter was partially changed by the Protocol of May 15, 2004. The Protocol was signed by 41 member states of the Council of Europe, and 7 have already ratified it.

${ }^{9}$ Linkevicius, L. A Broader Concept of Security for the 21 st Century, speech delivered at the "21st International Seminar of Global Security" in Berlin, on May 8, 2004.
} 
lic of Lithuania until the next review of the National Security Strategy will be determined by the following distinguishing features of the current security environment:

- Final preparations for entry into NATO and the EU,

- Addressing the challenge of international terrorism."10

Next to this, among the major factors to influence Lithuania's international situation in the period of the coming fifteen years, indicated in the Seimas "Decision on the long-term strategy for development of the state", of November 12, 2002, international terrorism is not even mentioned while the Decision only refers to the factors influencing the world security and stability as well as non-traditional threats. ${ }^{11}$

It should be noted that the spread of transnational terrorism in the NSS is directly coupled with globalization (Paragraph 4.1), and the terrorism itself "poses a serious security threat to the global community, and therefore to Lithuania as well. However, this threat is largely external to the Republic of Lithuania. The internal situation and the historical heritage of Lithuania do not provide conditions for the formation of a broad domestic network of terrorism. This danger stems primarily from abroad." (Paragraph 4.1.1). Nonetheless, it is recognized that the infrastructures of Lithuania, strategic and objects of foreign countries 'may become a potential target of international terrorism.' (Paragraph 4.1.1) Globalization is ambiguously evaluated also in the "Strategic plan of action for the years 2004-2006" of the Ministry of Interior, where it is stated that 'globalization brings not only positive changes to the social live. It also causes threats of international terrorism and international crime. ${ }^{12}$ Another document, foreseeing the negative effect of globalization, is the Lithuania's Military Strategy (renewed in October of 2004), which says that 'there are no states that are immune against international terrorism' adding that 'chances of nontraditional threats are growing.' (Paragraph 2.3). ${ }^{13}$

These (main) antiterrorist documents that have been passed in Lithuania and are publicly accessible give an impression that the perception of globality of terrorism (or, to be more precise, of the international terrorism as an effect of globalization) is comprehended on the highest political level. However, a deeper and more

\footnotetext{
${ }^{10}$ National Security Strategy of the Republic of Lithuania, adopted on May 28, 2002, http:// www.kam.lt/EasyAdmin/sys/files/NSS.doc (English), http://www.kam.lt/EasyAdmin/sys/files/Nacionalinio_saugumo_strategija_06_05.doc (original Lithuanian), November 15, 2004.

As the final provisions (Paragraph 7.5) of the Strategy state, "The procedures for preparation, adoption, implementation and review of the National Security Strategy are established by the Law on the Basics of National Security of the Republic of Lithuania“, which was adopted back in 1996 and has since been numerous times amended. Although the Law on the Basics of National Security pays some attention to the threats of terrorism, it is not elaborate on the issue. (http://www3.lrs.lt/ cgibin/getfmt?C1 =w\&C2=228593, original Lithuanian, http://copyright.iile.ru/law/indexlit.html, English, November 15, 2004.

${ }^{11}$ Seimas' "Decision on the long-term strategy for development of the state", Nr. IX-1187, November 12, 2002, p. 7, http://www.lrv.lt/strateginis/igal_strat.pdf (original Lithuanian), November 11, 2004.

${ }^{12}$ Ministry of Interior of the Republic of Lithuania, Strategic plan of action for the years 2004-2006, http://www.vrm.lt/index.php?id=360 (original Lithuanian), November 15, 2004.

${ }^{13}$ Military Strategy of the Republic of Lithuania, http://www.kam.lt/EasyAdmin/sys/files/strategija.doc (original Lithuanian), November 15, 2004.
} 
comprehensive analysis of these and other documents as well as the official antiterrorist rhetoric allows to differentiate between the official naming of this complex phenomenon called terrorism and the real perception of its essence and structure as well as readiness to deal with its threats.

Threats, which are associated with terrorism and are identified in various political documents, are distinguished into those related to terrorist attacks on the territory of Lithuania and the ones which are 'transit' in respect to Lithuania. 'Transit' threats are those that can eventuate a terrorist attack outside of Lithuania. This is residence in or transit of terrorists across Lithuania, founding of a terrorist group or planning of a terrorist attack in Lithuania, illegal acquisition of weapons and substances needed for attack, opening and keeping of bank accounts in Lithuanian banks, performance of other financial operations through Lithuanian finance institutions. This distinction is stated in both the NSS (Paragraph 4.1.1) and the Military strategy. The State Security Department (SSD) - the main acting organization in the prevention of terrorism - also distinguishes between the aspects of the place of terror and the corridor of terrorists' transit. ${ }^{14}$

Officially declared real threats for Lithuania that are associated with terrorism are ascribable to the illegal usage of deadly (radioactive, biological and chemical) substances and threats caused by immigration (both legal and illegal).

\section{Lithuania in the World: International Cooperation}

In the autumn of 2001 it appeared as if Europe awoke when it became apparent that the net of terrorists in the Old Continent is not only extremely dense, but also extremely sophisticated and refined. Massive surveillance and arrests started ${ }^{15}$ (almost every week in one or another state of Europe persons who are directly involved in terrorist activity are being arrested, police often detects caches of guns and explosive), which were followed by trials and banishments, dispersals of religious and charity organizations, freezing of financial resources, etc. All this was crowned by a series of antiterrorist laws, which were passed within concrete states as well as on an international level. These measures in one or another way have affected (and still are affecting) practically all estimated 23 million Muslims who live in Europe.

To use the above mentioned metaphor, Lithuania apparently does not belong to the camp of 'deliberate exporters' of terrorism. On the contrary, it with the whole its political body and heart swears its loyalty and support for the camp, which fights against the import (e.g. international terrorism), and in particular its flagman - USA, and demonstrates that devotion constantly. The NSS unambiguously states that as

\footnotetext{
${ }^{14}$ Official website of the Lithuanian State Security Department, http://www.vsd.lt/default.asp?page $=91$, November 14, 2004.

${ }_{15}$ Roland Jacquard, the president of the Paris-based International Observatory on Terrorism, estimates that more than 200 people accused of involvement with terrorism have been arrested in several European countries, including Belgium, Britain, France, Germany, Italy and Spain, in less than a year from the September 11, 2001 tragedy. Walt, V. "Terrorists 'spread all over Europe", USA Today, July 21, 2002, http://www.usatoday.com/news/world/2002-07-21-alqaeda_x.htm, November 8, 2004.
} 
well: "The Republic of Lithuania continues to provide political and practical support for the antiterrorist campaign of the United States, after they became the targets of terrorist attacks on 11 September 2001." (Paragraph 6.1.1). However, due to limited resources and capabilities, on the international level, this is realized more in rhetorical and formal (diplomatic) way. ${ }^{16}$

The NSS presupposes (particularly in Paragraph 4.1.1) that Lithuania can not become a member of terrorism exporters' camp, meaning that from the point of terrorism ideology, individual terrorists and their organizations, Lithuania does not pose any potential threat to the world. Nevertheless, as shown above, Lithuania theoretically can become a target and a victim of terrorism, that is, an importer of international terrorism. For this reason, the preparedness to deal with threats associated with terrorism should be one of the priorities in ensuring stability and security in the state.

Lithuania has declared its determination to fight against international terrorism on repeated occasions. One of the expressions of this determination is the ratification of all $12 \mathrm{UN}$ antiterrorist conventions. The 'International Convention for the Suppression of Terrorist Bombing' was the last to be ratified by the Seimas in December of 2003.

Obviously, one of the best-seen and emphasized expressions of practical cooperation in the fight against terrorism is the participation of Lithuanian soldiers in international missions in Afghanistan and Iraq, which are commonly considered to be as antiterrorist operations. The Military Strategy of Lithuania approves the determination and commitment to adhere to 'the international NATO, EU, UN, OESC and also ad hoc coalitions which implement the objectives of these organizations (...) Lithuanian military will participate in the actions to prevent sources of terrorism, seeking to stop the spread of terrorism.' (Paragraph 4.4) This is also stated in the "Decision on the long-term strategy for development of the state": 'Lithuania will participate actively in NATO peace missions according to its resources, firstly in better known regions, where Lithuania already has experience ${ }^{117}$, passed a couple of years ago by the Seimas.

After repeated discussions in the beginning of autumn of 2004, the term of Lithuanian troops' participation in international missions was eventually extended. The total number of troops to participate in international missions is 330 ( 70 of them in Afghanistan, 120 in Iraq). The Ministry of Defense seems to be one of the most determined political institutions, seeking for a long-term Lithuanian troops' participation in international operations. The then Minister of Defense Linkevicius has

\footnotetext{
${ }^{16}$ See speeches by President Valdas Adamkus, officials of the Ministries of Foreign Affairs and Defense, Lithuanian representatives at international organizations and joint communiqués signed by Lithuanian officials. (http://www.lt-mission-eu.be/MissionNATO/current/lithuania_reacts to the september 11 terror acts.html, November 15, 2004. On the practical level, Lithuania's input is rather modest: next to opening its air and land space for transit of allied troops and sharing intelligence information, $t$ could offer only several hundred troops and a dozen medical personnel to take part in the so-called anti-terrorist operations in Afghanistan and Iraq. In addition, Lithuanian Government contributed several hundred thousand Litas for rebuilding works in the regions of operations.

${ }^{17}$ Seimas' "Decision on the long-term strategy for development of the state", Nr. IX-1187, November 12, 2002, p. 21, http://www.Irv.lt/strateginis/igal_strat.pdf (original Lithuanian), November 11, 2004.
} 
labeled almost all ongoing operations as antiterrorist and has constantly reasoned the necessity of Lithuania's participation in them firstly out of its commitments to take an active part in the antiterrorist drive headed by the USA. However, the Ministry has so far failed to come up with a definition of terrorism that it adheres to; so, the perception of terrorism in the Defense system remains somewhat vague and flexible, moreover, it is clearly dependent on the U.S. foreign policy. This causes several problems. For instance, should an armed resistance against occupying forces be regarded as terrorism? For example, is the fight of Afghans and Iraqis against the U.S. and the allied military stationed in those countries terrorism? The answer to this question in the Lithuanian Defense system is straight forward - yes. However, in definitions of terrorism and in the international law, used worldwide, partisan (resistance to occupation or liberation) war is dissociated from terrorism. Unfortunately, in the Lithuanian Defense system, there is a lack of critical assessment of terrorism as a phenomenon, and the functional attitude, which prioritizes international commitments of the country as well as political mimicry in the fight against terrorism, dominates the scene.

\section{Internal measures}

The NSS covers a set of measures of terrorism prevention on the territory of Lithuania: "developing general anti-terrorist legislation; protecting potential targets against terrorist attack - including critical infrastructure; identifying individuals involved in ordering and executing possible terrorist acts; identifying and removing potential sources of terrorist funding; establishing clearly defined procedures for investigating acts of terrorism; systematic preparation for eliminating crisis situations caused by acts of terrorism; reinforcing counter-terrorist intelligence capability." (Paragraph 6.1.5). These and other measures are reinforced by documents, which regulate the antiterrorist activities of respective governmental agencies around the country.

It would be expected that having such a perception of global terrorism threats that is stated in aforementioned documents, the Lithuanian Government should have already assumed certain measures in order to form responsible structures and units staffed with specialists, who have studied and gained practical expertise abroad and are able to promptly figure out ideological orientations, relations and activities of single individuals as well as groups, and capable of both preventing and liquidating the damage caused by terrorist acts. Unfortunately, after going deeper into the structure and functions of public institutions, which should be responsible for fight against terrorism, it appears that there either are no separate structural units or their functions do not include the sphere of terrorism prevention and fight against it.

For example, the Migration department at the Ministry of Interior is a mere bureaucratic unit, which carries on only formal procedures and has no measures or commissions to exercise prevention of terrorism. The State Border Guard Service at the same ministry does not either speak about any specific terrorism prevention measures except the regular routine, though this institution is the most important in filtering potential incoming terrorists. Ministry of Defense generally does not officially consider terrorism prevention to be one of its spheres of activities, though enormous finances for the fight against terrorism come into disposition of this parti- 
cular institution. And in the Ministry of Justice, there is also no unit, the personnel of which would be charged with supervising this sphere.

The State Security Department is about the only governmental agency to declare on its website that antiterrorist activities are part of its daily schedule. ${ }^{18}$ But even in this case, concrete forms of these activities and their fruitfulness depend on specialists who are working on them. ${ }^{19}$ In October of 2004, the SSD presented its action strategy for the years 2005-2008, in which it is intended 'to develop a system of international terrorism prevention'. ${ }^{20}$

The antiterrorist operations squad of the Lithuanian police 'Aras' is the unit charged with implementing concrete antiterrorist activities. The former rapid deployment squad of the Lithuanian police 'Aras' was renamed as 'antiterrorist operations squad' in November of 2004. This squad according to its set regulations has to 'carry out special antiterrorist, hostage freeing, and operations to arrest dangerous criminals; to neutralize self-made and military explosions, which are used for terrorist or criminal purposes.' (Paragraphs 8.1, 8.2)

\subsection{The definition of terrorism: criminalization of the phenomenon}

In order to prepare for the fight against terrorism effectively, there must be a clear (and stated in laws) perception of the phenomenon of terrorism. Trying to find out if there is any such perception, the definition of terrorism could be a starting point. Unfortunately, none of the antiterrorist documents mentioned above define what is to be considered terrorism. ${ }^{21}$ This allows for a danger that the actual efforts of terrorism prevention undertaken by state agencies become at times suspicious and even pointless and obsolete without at least a publicly available working definition, for there seems to be no real ground against which the undertaken activities could be judged.

The only publicly available definition of terrorism is to be found in the Article 250 of the Criminal Code (under the heading 'Act of terror'), where it is set forth

\footnotetext{
${ }^{18}$ On the official website of the State Security Department, (http://www.vsd.lt/default.asp?page $=91$, November 13, 2004), it says: "Antiterrorist Activities: As Lithuania is increasingly integrating into the world community, the necessity is arising to take measures so that the country does not become a target for terrorist acts or a transit state for terrorists. To this end, the State Security Department works to prevent terrorist actions and fights causes facilitating the spread of terrorism. The Department gathers and analyses information, and identifies persons who belong to terrorist groups, support them, or have extremist tendencies. In fighting terrorism, the SSD cooperates actively with foreign services and law enforcement agencies of the Republic of Lithuania. The Department also submits proposals to the Government on how to improve the existing laws, and on how to coordinate the activities of law enforcement agencies in order to make the prevention of terrorism more effective."

${ }^{19}$ According to Roland Jacquard, one of the main factors, hampering effective antiterrorist activities is shortage of secret agents versed in 'terrorist' languages. Walt, V. Terrorists 'spread all over Europe', USA Today, July 21, 2002, http://www.usatoday.com/news/world/2002-07-21-alqaeda_x.htm, November 8, 2004. Lithuanian State Security Department, as far as the author is aware has not a single employ with fare knowledge of either Urdu, Pashto, Farsi or Arabic.

${ }^{20}$ BNS, October 14, 2004.

${ }^{21}$ The only document, which contains a definition of terrorism, is the Program against Terrorism, which unfortunately is out of the reach of the public. Accidentally, the only official definition of terrorism is made classified. This is at the same time pathetic and sad.
} 
through the definition of an act of terror. According to the Criminal Code, the act of terror is placement of explosives in order to trigger explosion, blasting or setting the fire in human settled, working, gathering or public places. The same article also talks about terrorist group, defining its aims as attempt to employ previously mentioned 'actions to frighten people or to demand illegally from the state or its institutions or international organizations to perform or to suspend particular actions.'

However, the definition of terrorism used in the Criminal Code is a problematic one. Government of a particular state can use terror against its own citizens or inhabitants of occupied territories. As E. V. Walter has forcibly shown, it is necessary to distinguish between terror that is invoked by state and non-state actors. ${ }^{22}$ The government pursued terror can be called 'reign of terror' or 'reigning by terror' and terror of non-state actors is called 'siege of terror'. The latter terror is synonymous to terrorism. Unfortunately, the Criminal Code of Lithuania does not take into account such distinctions.

To make matters worse, the provided definition considers neither motivation nor aims. It is true that talking about terrorist groups, their aims are loosely indicated, however they not necessarily have to be political. According to the article of the Criminal Code, the frightening of people or illegal demands from the state, its institutions or international organizations to perform or to forgo various tasks can be exercised seeking economical benefits without any political motivation or aims behind.

The provided definition of an act of terror does not foresee terror to be not just a mere single accident but continuous - e.g. 'process of terror' (as formulated by Walter). But it is precisely the feature of continuity which makes illegal coercion and violence terrorism. Threatening to use illegal coercion or violence is not mentioned in the definition altogether, though most of definitions include it into the notion of terrorism. Moreover, the definition of an act of terror is especially problematic because it includes only a few actions - blowing up and arson while the list of terrorist actions in the world is much longer. And finally, the Article 250 of the Criminal Code does not distinguish between targets - state security and military structures (uniformed officers serving in them, their objects as well as other movable and immovable property) and civilians, nonmilitary objects and private property. It causes some difficulties in classifying sallies against police officers as an act of terror.

But that is exactly what happened in the autumn of 2004, when a stationary police office was set on fire in the Vilnius Roma tabor in the Kirtimai district on October 6.During the press conference, the head of Vilnius Police Department Erikas Kaliacius evaluated this action as an act of terror. The Organized Crime Investigation Service of the Vilnius PD started pretrial investigation in this incident (which is officially regarded as an act of terror) ${ }^{23}$ According to the Criminal Code, the custodial sentence for this kind of crime ranges from five to fifteen years. As it turned out it was two young junkies who had been working as day laborers in the tabor who caused the arson. According to information that is available publicly, this arson was not premeditated or systemically planned. Presumably, it was an irascible reaction of

${ }^{22}$ Walter, E. V. "Violence and the Process of Terror", American Sociological Review, vol. 29, issue 2, 1964.

${ }^{23}$ BNS, October 6, 2004. 
the local Roma towards the attempts by the Vilnius municipality and police to restrain drug dealing in the tabor. It is impossible to find any political motivation in this ruffian action. Unfortunately, thanks to the Criminal Code even such a trivial crime can be treated as a manifestation of terrorism.

Several articles of the Criminal Code discuss other features typical of terrorism. For instance, Article 145 ('Threatening to Kill, Heavily Damage Person's Health or Terrorizing of People') speaks about threatening to kill a person or to damage his/her health seriously. The article also mentions terrorizing of a person threatening to blow up, to arson or to perform other actions that are dangerous to human live, health or property as well as systematical terrorizing using psychological coercion. Article 251 ('Seizure of Aircraft, Vessel or Stationary Platform in the Continental Shelf') criminalizes particular actions that are stated in international agreements: seizure of aircraft, vessel or stationary platform in continental shelf using or threatening with physical violence. Kidnapping of human person (Article 252, "Kidnapping of Human Person") (both having or not having political aims) also is regarded as a crime to be punished according to the criminal Code: 'The one, who kidnapped or kept imprisoned a person and demanded from international public organization, state or its institution to perform or to restrain any action and also the one, who threatened to kill the kidnapped person insisting on facilitating his escape from arrest, is to be punished...'

The recent Supplement to the Criminal Code (initiated by the Chairman of the Seimas National Security and Defense Committee Alvydas Sadeckas) should be seen as additional efforts to criminalize not only terrorist actions, but also public approval of them. In the Law of the Supplement, passed by Seimas on November 8, 2004, a punishment is designed for dispersal of information (in written, orally, or in any other way), which encourages, supports, or justifies terrorist activity, terrorist group, a person who performs terrorist acts as well as despises victims of terror. ${ }^{24}$ In the words of Sadeckas: 'the propagation of terrorism endangers the security of the state and society; therefore, it should be criminalized. ${ }^{25}$ This step of the Seimas Committee was a direct reaction to the case of the Kavkaz Center Internet site, which has reached the Constitutional Court and awaits its ruling. However, the initial move came out of the SSD, which is the plaintiff in this lawsuit. This was indirectly confirmed by Sadeckas himself. ${ }^{26}$

Terrorism is being criminalized in Lithuania in agreement with the world practice. For example, in the UN General Assembly Resolution (1994), 'the States Members of the United Nations solemnly reaffirm their unequivocal condemnation of all acts, methods and practices of terrorism, as criminal and unjustifiable, wherever and by whoever committed. ${ }^{27}$ In the report (2002) of the UN Policy Working

\footnotetext{
${ }^{24}$ Supplement to the Criminal Code (addition of the Article 250(1), http://www3.lrs.lt/cgi-bin/ preps2?Condition $1=244809 \&$ Condition2 (original Lithuanian), November 15, 2004.

${ }^{25}$ BNS, October 6, 2004.

${ }^{26}$ BNS, October 6, 2004.

${ }^{27}$ UN General Assembly Resolution A/RES/49/60 Measures to Eliminate International Terrorism, 1994, http:/www.un.org/documents/ga/res/49/a49r060.htm, November 11, 2004.
} 
Group, it is stated that 'terrorism is a criminal act' adding long-sightedly that 'it is more than mere criminality'. ${ }^{28}$ The European Parliamentary Assembly, in its recent (2004) Recommendation No. 1644, among other things maintains that 'the motive behind an act of terrorism does not change the nature of that act. Terrorism has no justification and it must be considered illegal, abhorrent, unacceptable and a crime against humanity'. ${ }^{29}$ The Organization of the Islamic Conference similarly states in its resolution that "Terrorism" means any act of violence or threat thereof notwithstanding its motives or intentions perpetrated to carry out an individual or collective criminal plan with the aim of terrorizing people or threatening to harm them or imperiling their lives, honour, freedoms, security or rights or exposing the environment or any facility or public or private property to hazards or occupying or seizing them, or endangering a national resource, or international facilities, or threatening the stability, territorial integrity, political unity or sovereignty of independent States'.$^{30}$ Moreover, the Organization of the Islamic Conference does not subsume politically motivated murders and assassinations under 'political crimes' ${ }^{31}$ The Commonwealth of Independent States in its antiterrorist treaty places terrorism within the confines of the Criminal law: 'Terrorism' - an illegal act punishable under criminal law committed for the purpose of undermining public safety, influencing decision-making by the authorities or terrorizing the population. ${ }^{32}$

Nevertheless, assigning of terrorism exclusively to the realm of the criminal justice is doubtful. The criminal justice examines only the substance of the offense while the motives or objectives are regarded only as extenuating or aggravating circumstances not to be examined in detail or sought to eliminate. Leaving terrorism for the criminal justice, the roots (social, economic, and the most important - political) of this complex phenomenon remain unaccounted for and therefore not analyzed. Thus, the criminalization of terrorism, which enables to cope with the consequences of terrorism (to prosecute terrorists, who actively prepare for or have already made a sortie, and their collaborators), does not at all cover reasons for the fight against terrorism.

\footnotetext{
${ }^{28}$ Report of the Policy Working Group on the United Nations and Terrorism, 2002, http://www.un.dk/ doc/A.57.0273_S.2002.875.pdf, http://www.globalsecurity.org/security/library/report/2002/unwrkng-grp-terrorism.htm, November 11, 2004.

${ }^{29}$ Terrorism: a threat to democracies, EU Parliamentary Assembly, Recommendation No. 1644, 2004, http://assembly.coe.int/Documents/AdoptedText/ta04/EREC1644.htm\#_ftnref1, November 14, 2004.

${ }^{30}$ Annex to the Resolution 59/26-P, Convention of the Organization of the Islamic Conference on Combating International Terrorism, 1999, Article 1, Point 2, http://www.oic-un.org/26icfm/c.html, November 11, 2004.

${ }^{31}$ Annex to the Resolution 59/26-P. Convention of the Organization of the Islamic Conference on Combating International Terrorism, 1999, Article 2, Point c, http://www.oic-un.org/26icfm/c.html, November 11, 2004.

${ }^{32}$ Treaty on Cooperation among the States Members of the Commonwealth of Independent States in Combating Terrorism, Article 1, 1999, http://untreaty.un.org/English/Terrorism/csi_e.pdf, November 11, 2004.
} 


\subsection{Readiness of state institutions}

The Civil Protection Department (CPD) started orienting its work towards liquidation of consequences of possible terrorist attacks after the September 2001 attacks in the USA. As it is said on the Internet site of the CPD, 'in Lithuania, there are lot of sources of extreme situations, which can cause effects on peoples' lives and health. They are nuclear power plant at Ignalina, more than 250 of chemically dangerous objects, transportation of dangerous chemical substances, the communication system, oil industry, nets of gas pipes and pipelines. The possibility of terror or sabotage acts can not be rejected. ${ }^{33}$ Lithuania has already prepared a program how to liquidate ravage of extreme situations caused by terror acts. The measures are to be implemented till the year 2010.34 The CPD organizes interdepartmental meetings for the effective implementation of provided measures. In addition to this, the international practice how to liquidate the oil spillage, caused by a terror act, had been arranged in June of $2004 .^{35}$ In its website, the CPD advises, how to deal with chemical terrorism. Incidentally, particularly a senior specialist of the CPD Arvydas Paršaitis is the only state clerk to have publicly used a sort of definition of terrorism: 'Terrorism is a deliberate, mostly politically motivated violent activity, which targets civilized states and their citizens and is counter to universally recognized rules of law - the fundament of contemporary civilization. ${ }^{36}$ This perception of terrorism is questionable, however, efforts of this clerk to define the phenomenon itself, ravage of which is to be dealt with by his institution in the case of terrorist attack, should be commended.

Another institution charged with dealing with possible terrorism ravage, the Fire and Rescue Department (FRD) in its 'Program for the implementation of the Strategy for the development of public security till 2010 in the fire and rescue system' stated that 'FRD-governed institutions are neither prepared enough nor materially equipped with special personal and work tools. Moreover, it lacks in legal acts, which would regulate the organization of rescue works. ${ }^{37}$ This is recognized in a broader manner in the 'Program for the elimination of the ravage of extreme situations caused by terror acts' (original Lithuanian 'Teroro aktu sukeliamu kriziniu situaciju padariniu likvidavimo programa', passed on June 26, 2003; No. 850): 'preparedness to liquidate ravage of weapons of massive destruction is not yet satisfactory.' Thus, despite a clear understanding of this kind of threat, explicitly stated in a range of

\footnotetext{
33 The official website of the Civil Protection Department, http://www.csd.lt/csg/ekst_situac.php, November 15, 2004.

${ }^{34}$ Paršaitis, A. Civilines saugos departamentas apie terorizmo gresme (the Civil Protection Department on the threat of terrorism), http://195.182.90.36/news/naujienos_det.asp?id=178\&menuo $=$ Bir $\bullet$ elis, (original Lithuanian), November 15, 2004.

${ }^{35}$ Gyventoju veiksmai teroristams panaudojus chemini masinio naikinimo ginkla, (Actions of the population in case of terrorists' usage of WMD), official website of the Civil Protection Department, http://www.csd.lt/patarimai/p.php?n=16 (original Lithuanian), November 15, 2004.

${ }^{36}$ Paršaitis, A. Civilines saugos departamentas apie terorizmo gresme (the Civil Protection Department on the threat of terrorism), http://195.182.90.36/news/naujienos_det.asp?id=178\&menuo $=$ Bir $\bullet$ elis (original Lithuanian), November 15, 2004.

37 „Viešojo saugumo pletros iki 2010 metu strategijos igyvendinimo programa valstybineje priešgaisrineje gelbejimo tarnyboje“ (Program for the implementation of the Strategy for the development of public security till 2010 in the fire and rescue system), Fire and Rescue Department Director's order nr. 217, November 7, 2002.
} 
documents and statements made by the highest state officials, and efforts that are being put, the Lithuanian Government admits that the situation is not yet satisfactory.

As the Press release of the Press Office of the Lithuanian Government states, seeking to coordinate effectively antiterrorist activity, 'the Government decided to found a joint committee against terrorism', which is to be headed by the Director general of the SSD. Furthermore, the same release says that 'the committee will consider strategic and immediate questions relating to the fight against terrorism and terrorism prevention, will control the implementation of the Program against terrorism. Joint committee will offer suggestions for State Defense Council, the Seimas National Security and Defense Committee and for other public institutions and agencies. Sessions of the Joint Committee are to be held at least once in three months. ${ }^{38}$ The Committee consists of high ranking officials from almost two thirds of ministries (Interior, Foreign Affairs, National Defense, Transportation, Environment, Economy, Finances and Health), officials from the SSD and the General prosecutor's office. However, the usefulness of this committee is not perceptible due to the secrecy of information.

The drawbacks and limitations of the Program against terrorism can be certified by the proposal of the Seimas to renew it. In July of 2004, these proposals were favored and a plan to prepare long-term consolidation of security programs was approved. Among the suggestions was one "to frame projects of laws defining the list of objects that are vulnerable to terrorism and measures to consolidate their safety; to consider a possibility to move the Refugees Reception Center out of Rukla; to tighten air traffic control at small airports', and most importantly, to charge the SSD 'with preparation of the project of the Law for fight against terrorism. ${ }^{39}$

\section{Conclusions}

The contemporary terrorism is both a consequence and a reaction to the continuous disbalance of powers as well as international relationships based on principals of hegemony. Therefore, only after critical analysis of the policies of the European empires and their descendant the USA vis-ą-vis the Asian countries, not only roots of the latter-day terrorism can be traced, but also evaluation of adequacy and efficiency of the current antiterrorist measures can be made.

Lithuania so far is neither an exporter nor an importer of terrorism. Being not influential in world processes and in decisions made by the great powers, it is not really regarded (although it thinks of itself) as a potential partner by terrorism-fighting states or as a potential enemy by terrorism exporters. Such an impotent status can

${ }^{38}$ Press release of the Press Office of the Government of the Republic of Lithuania, February 13, 2002, http://buves.lrv.lt/aktualij/pran_sp/2002vasaris/terorizmas_komisija05.html (original Lithuanian), November 15, 2004.

${ }^{39}$ LR Seimo Nacionalinio saugumo ir gynybos komiteto Sprendimas del Programos prieš terorizma igyvendinimo (Decision of the Seimas National Security and Defense Committee on implementation of the Program against terrorism), March 31, 2004, nr.1, http://www3.lrs.lt/pls/inter/w3_viewer.ViewDoc?p_int_tekst_id $=32670 \& p_{-}$int_tv_id $=409 \& p \_o r g=0$ (original Lithuanian), November 12, 2004. Itself, the 'Program against terrorism' is a classified document unavailable to the general public. 
misleadingly appear to be beneficial - terrorism might miss us. It is highly likely to be so for a while. However, in a long perspective, this situation will become dangerous.

The problem is complex and its solution demands more than just good political will from the Government's side. Formal statements that Lithuania is on the side of the fighters against terrorism exporters does not make by itself Lithuania strong and resistant to terrorism. The first steps undoubtedly have been taken on the political level, however. The Lithuanian Government swore to cope with terrorism in its 'Program against terrorism' (passed on October 22, 2002) and allocated some $7,000,000$ Litas for this purpose. ${ }^{40}$ Moreover, structural units in public institutions are being created and the Joint Committee, which coordinates proceeding of various institutions, has been found.

Nonetheless, though the enactment of laws and other documents and creation of various structures are implemented without difficulty, to fill them with real specialists seems to be not such an easy task. Specialists here mean professionals having appropriate education as well as practice. Unfortunately, Lithuania lacks such specialists chronically. In the sense of education, the situation is pitiable because there are not only no academic programs but also no separate courses on terrorism at the Lithuanian establishments of higher education. Accordingly, no surveys are being carried out in this sphere. Academic programs and research in studies of security regrettably do not pay enough attention to the analysis and studies of the phenomenon of international terrorism. On the level of practical skills, clerks of respective Lithuanian public institutions should have to have possibilities to work in institutions of states dealing with and fighting against terrorism.

Thus, the essential task for Lithuania in the context of the current antiterrorist drive is not an automatic justification of antiterrorist measures that are underway in the name of peacefulness in a not defined future, but formation of critical attitude both on political and social levels. Only after formation of versatile realization of terrorism as a phenomenon (its sources, nature of its threats and methods) and formulation of a viable and publicly available definition of terrorism, Lithuania can attain adequacy of its antiterrorist programs and measures implementing them in a long-term prospect. In turn, it would be crowned with the success of antiterrorist activities and avoidance of loss of life and property.

\footnotetext{
${ }^{40}$ In the 2003 budget financial assignations for fight against terrorism were even increased, allocating to the State Security Department 2,904,000 Litas, to the Police Department - 6,100,000 Litas. (source: Seimas Budget and economic affairs committee)
} 